\section{JURNAL NERS DAN KEBIDANAN INDONESIA INDONESIAN JOURNAL OF NURSING AND MIDWIFERY}

\title{
Breastfeeding and adherence to ARV treatment with mother-to-child transmission of HIV at Sosodoro Djatikoesoemo Hospital, Bojonegoro
}

\author{
Endah Sri Wulandari ${ }^{*}$, Ayun Wiwaningtyas ${ }^{2}$ \\ ${ }^{1}$ Universitas Negeri Semarang, Jalan Kelud Utara III, Petompon, Kec.Gajah Mungkur, \\ Kota Semarang, Jawa Tengah \\ ${ }^{2}$ STIKES Insan Cendikia Medika Jombang , Jalan Kemuning No.57A, Candi Mulyo, \\ Kec. Jombang, Kabupaten Jombang, Jawa Timur \\ *Corresponding author: wulanendah4@gmail.com
}

\begin{abstract}
ABSTRAK
Latar Belakang: Virus HIV dapat ditularkan dari ibu yang terinfeksi HIV kepada anaknya selama kehamilan, saat persalinan dan saat menyusui. HIV yang terjadi pada anak didapat karena penularan dari ibu yang tidak patuh minum obat anti retroviral ataupun saat pemberian ASI. Pencegahan penularan HIV dari ibu ke anak adalah upaya yang ditujukan untuk mencegah penularan dari ibu ke anak yang dilakukan secara terintegrasi dan kompehensif dengan program-program lainnya yang berkaitan dengan pengendalian HIV.

Tujuan: Tujuan penelitian ini untuk mengetahui hubungan pemberian ASI dan kepatuhan pengobatan ARV dengan penularan HIV dari ibu ke anak di RSUD Sosodoro Djatikoesoemo Bojonegoro.

Metode: Variabel dalam penelitian adalah variabel independen pemberian ASI dan kepatuhan pengobatan ARV pada ibu dan variabel dependen status HIV pada balita. Jenis penelitian menggunakan analitik kolerasional dengan desain cross sectional, dengan populasi sebanyak 25 ibu yang mempunyai bayi usia 0-6 bulan dan sampel berjumlah 25 responden. Teknik non probability sampling, pengambilan sampel secara total sampling dengan instrumen penelitian menggunakan kuesioner, dan uji statistik menggunakan uji chi square.

Hasil: Penelitian ini menunjukan nilai signifikasi pada pemberian ASI yaitu $p=0,001$, sedangkan nilai signifikasi pada kepatuhan pengobatan ARV yaitu $p=0,009$. Artinya pada penelitian ini yang paling dominan mempengaruhi status HIV pada balita adalah pemberian ASI.

Kesimpulan: Penelitian ini dapat dianalisis upaya untuk mengatasi masalah maternal dengan status HIV untuk meningkatkan kesadaran ibu dengan status HIV tetap memeriksakan diri baik saat hamil maupun setelah melahirkan agar dapat meminimalisir penularan pada balitanya.
\end{abstract}

KATA KUNCI : pemberian ASl; kepatuhan pengobatan ARV; HIV pada balita

\section{ABSTRACT}

Background: The HIV can be transmitted from an HIV-infected mother to her child during pregnancy, childbirth, and while breastfeeding. HIV that occurs in children is acquired because of transmission from mothers who do not comply with anti-retroviral drugs or during breastfeeding. Prevention of mother-to-child transmission of HIV is an effort aimed at preventing mother-to-child transmission in an integrated and comprehensive manner with other programs related to HIV control.

Objectives: The study aimed to determine the relationship between breastfeeding and adherence to ARV treatment with mother-to-child transmission of HIV at Sosodoro Djatikoesoemo Hospital, Bojonegoro. 
Methods: The variables in the study were the independent variables of breastfeeding and adherence to ARV treatment in mothers and the dependent variable of HIV status in children under five. This type of research used a correlational analysis with a cross sectional design, with a population of 25 mothers who had babies aged 0-6 months and a sample of 25 respondents. Non-probability sampling technique, total sampling with research instruments using a questionnaire, and statistical tests using the chi-square test.

Results: The results showed the significance value of breastfeeding, namely $p=0.001$, while the significance value of adherence to ARV treatment was $p=0.009$. This means that in this study the most dominant influence on HIV status in toddlers is breastfeeding. Conclusions: This study can analyze efforts to address maternal problems with HIV status to increase awareness of mothers with HIV status to keep checking both during pregnancy and after delivery to minimize transmission to their toddlers

KEYWORD : breastfeeding; maternal ARV treatment; HIV status at toddler

Article Info:

Article submitted on February 04, 2021

Article revised on March 29, 2021

Article received on April 09, 2021

DOI: http://dx.doi.org/10.21927/jnki.2020.9(1).60-67

\section{INTRODUCTION}

Pregnant women infected with HIV can threaten the life of the mother and can transmit the virus to her baby. Cases under five are infected with HIV more than $90 \%$, transmitted through the process of transmission from mother to child (5).

In 2019 , about $90 \%$ of HIV cases infection in Indonesia that occurred in children under five caused by transmission from the mother and only $10 \%$ occurred due to the transfusion process (19). Since 2010 there have been 390 children aged 0-4 years infected with HIV, the number increased to 988 children in 2018. Meanwhile, the spread of HIV infection to children is due to the increase in the number of women infected with HIV. In 2017 there were 17,579 women infected with HIV and this number increased from the previous year (4). In the Sosodoro Djatikoesoemo Hospital, there are 25 toddlers with mothers whose HIV status is positive, whereof of the 25 toddlers there are 21 reactive toddlers and 4 non-reactive toddlers (3).

Non-compliance in the implementation of therapy will reduce the effectiveness of ARV drugs and even increase viral resistance in the body (8). The impact of a mother being exposed to HIV is an increase in maternal and child mortality and a decrease in the level of health of mothers and children in Indonesia (11).

Prevention of mother-to-child transmission of HIV is an effort aimed at preventing mother-to-child transmission in an integrated and comprehensive manner with other programs related to HIV / AIDS control and this program was first implemented in Sorong, West Papua (24). Mother-to-child transmission of HIV generally occurs during childbirth and breastfeeding, while mothers who do not breastfeed their babies have a $20-30 \%$ risk of HIV transmission and will decrease if the mother receives ARV treatment (11). Based on research Maulida \& Ghazali $20 \%$ of mothers who breastfeed realize that breastfeeding is the best nutrition for their babies, while breastfeeding mothers with HIV-AIDS choose not to breastfeed their babies because breastfeeding to their babies is considered to have a high risk of transmitting the disease to their babies (13).

Provision of short-term ARV and exclusive breastfeeding has a risk of HIV transmission of 
$15-25 \%$ and if the mother is not breastfeeding (PASI) the risk of transmission is $5-15 \%$. With long-term antiretroviral therapy, the risk of transmitting HIV from mother to child can be further reduced by $1-5 \%$, and mothers who exclusively breastfeed have the same risk of transmitting HIV to their children compared to mothers who do not breastfeed (16). Pregnant women with correct and adherent ARV treatment can suppress the HIV until the virus is not detected so that CD4 cells increase, and decrease the risk of transmission to the fetus (5).

HIV testing should be done from the beginning, namely for the bride and groom to be able to plan a pregnancy safely, but if the mother's HIV status is known from the start, comprehensive PMTCT interventions are carried out so that the mother does not transmit HIV to the baby she is carrying and if the mother is HIV negative then counseling on HIV is still carried out (15). The purpose of this study was to analyze between breastfeeding and adherence to ARV treatment in mothers with HIV status among children under five at Sosodoro Djatikoesoemo Hospital, Bojonegoro.

\section{MATERIALS AND METHODS}

This research uses analytical research. The design of this study used analytical research with a correlational type with a cross-sectional design. The research instrument used in data collection was a questionnaire. Researchers used a total sampling technique. The reason for taking total sampling is because the total population is 25 and the entire population is used as the research sample.

The main informants in this study were mothers with HIV who had children under five. Respondents were selected because mothers have an important role and are closest to their children, mothers with HIV positive status can be at risk of transmitting to their babies. Apart from mothers with HIV status, the informants in this study were nurses who served in the Sehati's out patien dept at Sosodoro Djatikoesoemo Hospital, Bojonegoro as the party who provided direct services to HIV patients. Data was taken from the main informant, namely mothers with HIV, checked by collecting data from mothers with HIV at the Sosodoro Djatikoesoemo Hospital.

Data analysis was used to determine the effect of the independent variable on breastfeeding and adherence to ARV treatment on the dependent variable, namely HIV status in children under five. Using the Chi-Square statistical test, with an error rate of $\alpha=0.05$. The test was used to analyze breastfeeding and ARV treatment adherence to HIV status in infants if the $p$-value (velue) $<\alpha(0.05)$.

\section{RESULTS AND DISCUSSION Univariate Analysis}

\section{Breastfeeding}

The results showed that most of the respondents did not breastfeed their toddlers as many as 22 respondents ( $88 \%$ ), but there were 3 respondents (12\%) who were still breastfed with HIV positive status. HIV transmission from HIV positive mothers to toddlers is also called vertical transmission that occurs through the placenta during pregnancy (intrauterine), during delivery (intrapartum), and post-natal through breastfeeding (18). Administration of ARVs has also been shown to be effective in a shorter time provided the baby is not breastfed, because the drug does not prevent transmission through breast milk (12).

Table 1. Distribution of breastfeeding for toddlers

\begin{tabular}{lcc}
\hline \multicolumn{1}{c}{ Breastfeeding } & Frequency & Percentage (\%) \\
\hline Breastfeeding & 22 & 88 \\
Formula Milk & 3 & 12 \\
\hline Total & 25 & 100 \\
\hline
\end{tabular}

The risk of HIV transmission from mother to baby through breastfeeding is caused by a low CD4 cell count, while the risk of transmission 
will increase if there are breast problems such as mastitis, sores, and abscesses in the breast, and even infection (17). HIV is also present in breast milk, although the concentration is much smaller than HIV in the blood, namely between $10-20 \%$ of babies born to HIV positive mothers will be infected with HIV through breastfeeding until the age of 18 months or even more (13).

According to the Ministry of Health Republic of Indonesia which shows that several factors affect the level of risk of HIV transmission through breastfeeding, namely the age of the baby, wounds in the baby's mouth, high concentrations of the virus, the mother's immune status, the length of breastfeeding and the presence of abscess or mastitis on the breast or injury nipple (10). Other factors that increase the risk of transmission during labor are the use of vacuum or forceps and episiotomy. This is consistent with this study, that breastfeeding from an HIV-infected mother is a risk factor for transmitting HIV infection to the baby. The longer breastfeeding, the cumulative the greater the risk of HIV transmission from mother to baby. Thus, shortening the period of breastfeeding can reduce the risk of infants becoming infected with HIV (7).

\section{Adherence to ARV treatment}

Based on the results of the study showed that all respondents consumed ARV regularly as many as 23 respondents with a total percentage (66.7\%). Accordingly adherence to ARV treatment during pregnancy is still high at Sosodoro Djatikoesoemoe Hospital, and adherence to ARV treatment in mothers during pregnancy also needs to be considered in addition to how to take medication adherence to other factors so that toddlers are also not infected with HIV. The maternal age factor shows that most of the mothers are $>35$ years old as many as 13 people. Also, family support is also very important in adherence to HIV treatment, especially for mothers during pregnancy.
Table 2. Distribution based on adherence to ARV treatment in women during pregnancy

\begin{tabular}{lcc}
\hline $\begin{array}{c}\text { Adherence to ARV } \\
\text { treatment }\end{array}$ & Frequency & Percentage (\%) \\
\hline Yes & 23 & 66.7 \\
No & 2 & 33.3 \\
\hline Total & 25 & 100 \\
\hline
\end{tabular}

The results of this study were in line with research conducted Wahyuni that adherence to ARV treatment greatly affects the transmission of HIV to their children. Mothers with good medication adherence are proven that their children are not infected with HIV from their mothers, while mothers who do not comply with treatment properly will infect their children. This is because the biggest inhibiting factor is the fear of opening status for fear of being discriminated against from the public and health workers (25). Based on the results of the study, it was explained that high ARV treatment made the group stable during pregnancy, thereby reducing the rate of HIV transmission to their child (20).

Treatment adherence requires active participation in self-care management and cooperation between patients and health workers where there will be a sense of trust between each other, so this compliance is very important to be created. Moreover, adherence or coolness to antiretroviral therapy is a key to successful treatment of HIV infection, because continuous ARV can reduce HIV infection until it is undetectable, reduce the risk of drug resistance, improve quality and survival, improve overall health, and can reduce the risk of HIV transmission (2). On the other hand, noncompliance of respondents with treatment is the main cause of therapy failure (21). HIV infection in children under five for which transmission is potentially postnatal from HIV positive mothers should be monitored regularly for 6 months after birth. PCR should be checked after birth, at 1-2 months of age, and 3-6 months of age. Infants who are infected usually manifest with growth failure 
and opportunistic infections (5). Counseling and offering HIV testing to all pregnant women, all pregnant women must be tested for HIV so that health workers can know the status of the patient so that they can provide proper health services. If the HIV status of pregnant women is known, the risk of HIV transmission from mother to child during pregnancy and childbirth can be prevented.

\section{Bivariate Analysis}

Breastfeeding and adherence ARV treatment with mother-to-child transmission of HIV Status in Toddlers

Based on the results of the study showed that most of the HIV status among children under five was negative as many as 19 under five with a total percentage $(57.6 \%)$ and 6 under five with a positive $\mathrm{HI}$ status with a total percentage $(18.2 \%)$. The risk factors for breastfeeding have a value of $p=0.001$ and adherence to ARV treatment with a significant value of $p=0.009$, meaning that the second factor shows a significant value $(\alpha<0.005)$. So the results of this study indicate that the most dominant influence on HIV status in children under five is breastfeeding. This can happen considering the many factors that can influence, namely in terms of maternal factors, toddler factors, and obstetric history factors themselves.

\section{DISCUSSION}

This is in accordance with Wahyuni research which explains that the level of compliance that is still low in following the PPIA program, especially the treatment of ARV while pregnant or breastfeeding causes the rate of transmission that occurs in the baby is still high caused by self esteem, support and stigma in the community (25). According to Tumangke, Tappy \& Kendek explained in his research that $58 \%$ of HIVpositive mothers could find HIV transmission to babies because mothers did not take ARV regularly until childbird so that it can transmit the babies who were breastfed, this was due to the low $\mathrm{K} 1$ and $\mathrm{K} 4$ coverage in the Jayapura region (23). Antretroviral Therapy (ART) in women with HIV that occurs in breastfeeding mothers can significantly reduce transmission to infants, but cannot eliminate HIV transmission. Therefore for breastfeeding mothers are not recommended to give breast milk to their babies (14).

In the research of Flynn et al. There were no significant results when stopping breastfeeding, both mothers who breastfed their babies quickly and mothers who breastfed their babies for

Table 3. Distribution based on breastfeeding with mother-to-child transmission of HIV

\begin{tabular}{cccccccc}
\hline \multirow{2}{*}{ Breastfeeding } & \multicolumn{3}{c}{ HIV status in toddlers } & \multicolumn{2}{c}{ Total } & \multirow{2}{*}{ p-value } \\
\cline { 2 - 7 } & \multicolumn{2}{c}{ Positive } & \multicolumn{2}{c}{ Negative } & & \\
\cline { 2 - 7 } & $\mathbf{F}$ & $\%$ & $\mathbf{F}$ & $\%$ & $\mathbf{F}$ & $\%$ & \\
\hline Breastfeeding & 19 & 86.4 & 3 & 13.6 & 22 & 100 & 0.001 \\
Formula Milk & 0 & 0 & 3 & 100 & 3 & 100 & \\
\hline Total & 19 & 86.4 & 6 & 24 & 25 & 100 & \\
\hline
\end{tabular}

Table 4. Distribution based on adherence ARV treatment with mother-tochild transmission of HIV

\begin{tabular}{cccccccc}
\hline \multirow{2}{*}{$\begin{array}{c}\text { Adherence } \\
\text { ARV }\end{array}$} & \multicolumn{3}{c}{ HIV status in toddlers } & \multicolumn{2}{c}{ Total } & \multirow{2}{*}{$\boldsymbol{p}$-value } \\
\cline { 2 - 7 } Treatment & \multicolumn{2}{c}{ Positive } & \multicolumn{2}{c}{ Negative } & & & \\
\cline { 2 - 7 } & $\mathbf{F}$ & $\%$ & $\mathbf{F}$ & $\%$ & $\mathbf{F}$ & $\%$ & \\
\hline Yes & 17 & 89.4 & 6 & 10.6 & 23 & 100 & 0.009 \\
No & 2 & 100 & 0 & 0 & 2 & 100 & \\
\hline Total & 19 & 86.4 & 6 & 24 & 25 & 100 & \\
\hline
\end{tabular}


a long time and each baby was still infected with HIV from the mother, therefore support for postpartum support is needed for mothers who are HIV positive (6).

In terms of baby factors, there are gestational age and baby weight at birth, breastfeeding period, and the presence of sores in the baby's mouth also greatly affect toddlers with HIV. HIV in children is most commonly infected via vertical transmission from mother to child, blood transfusions and the use of blood products are the second common route of transmission. Vertical transmission occurs at the end of pregnancy both before and after delivery. HIV gains access to the fetus through the placenta (intrauterine infection) or through a secret that directly contains HIV contact during childbirth (1). Prevention of mother-to-child transmission of HIV is a program of increasing concern as the incidence of HIV in mothers and children increases, so that with the efforts of transmission that occurs between mother and child the government has made a program through the implementation of PPIA on maternal and child health services (26).

Newborns of HIV mothers need to pay attention to immunization, although the guidelines recommended by WHO recommends that all immunizations can be done as long as the baby does not show clinical symptoms that lead to HIV (7). The results of research Solikhah \& Hadjam show that HIV infection reduces fertility, with causing neurotransmitters to be undisturbed as a result, fertility hormones are also disrupted and ultimately worsen the physical condition. However, some age groups indicate that most people with HIV are of childbearing age, so pregnancy in HIV positive women is a real problem (22).

According to Ministry of Health Republic of Indonesia a strategy in preventing motherto-child transmission of HIV that promotes a comprehensive approach that includes four components, namely: Primary prevention of
HIV infection in women of childbearing age, Preventing unwanted pregnancies in HIV-positive women, Preventing HIV transmission to women for their babies, and Providing appropriate care, care, and support for mothers living with HIV and their children and families. Despite various efforts over the years, it turns out that HIV coverage in maternal and neonatal cases is still low (9).

Based on the results of this study, it can be seen that several risk factors that have a statistically significant relationship to the prevention of mother-to-child transmission of HIV are breastfeeding, adherence to ARV treatment, and prevention of mother-to-child transmission of HIV.

\section{CONCLUSION AND RECOMMENDATION}

Based on the results of the study, several conclusions were obtained regarding maternal problems infected with HIV, that there is a relationship between breasfeeding and adherence to ARV treatment with the HIV status of toddlers. Meanwhile, the most dominant relationship is offering breast milk at Sosodoro Djatiekoesoemo Hospital, Bojonegoro was 25 respondents. Mothers are advised to increase their knowledge about maternal HIV and to remain in control to carry out examinations at the hospital to prevent early transmission of HIV to their toddlers as well as care for toddlers and also as consideration for planning for further pregnancies.

\section{REFERENCES}

1. Centers for Disease Control. (2016). Pediatric HIV Surveilance. Atlanta: CDC.

2. Debby, C., Sianturi, R., \& Hary, W. (2019). Faktor-Faktor Yang Berhubungan Dengan Kepatuhan Minum Obat ARV Pada Pasien HIV Di RSCM Jakarta. Jurnal Keperawatan, 10(1).

3. Dinas kesehatan Bojonegoro. (2020). Profil Kesehatan Kabupaten Bojonegoro. 
Bojonegoro: Dinas Kesehatan Kabupaten Bojonegoro.

4. Dinas Kesehatan Jawa Timur. (2019). Profil Kesehatan Provinsi Jawa Timur. Surabaya: Dinas Kesehatan Provinsi Jawa Timur.

5. Elisanti, A. D. (2018). HIV/AIDS, Ibu Hamil Dan Pencegahan Pada Janin. Yogyakarta: Budi Utama.

6. Flynn, P. M., Taha, T. E., Cababasay, M., Fowler, M. G., Mofenson, L. M., Owor, M., ... Stranix-, L. (2019). Prevention of HIV-1 transmission through breastfeeding: Efficacy and safety of maternal antiretroviral therapy versus infant nevirapine prophylaxis for duration of breastfeeding in HIV-1-infected women with high CD4 cell count (IMPAACT PROMISE): a randomi. Journal Acquir Immune Defic Syndr, 77(4), 383-392.

7. Isni, K., Shaluhiyah, Z., \& Cahyo, K. (2017). Pengetahuan Ibu HIV Mempengaruhi Perilaku Pencegahan Penularan HIVIAIDS dari Ibu ke Bayi di Provinsi Jawa Tengah. Jurnal Promosi Kesehatan Indonesia, 12, 2.

8. Karyadi, T. H. (2017). Keberhasilan Pengobatan Antiretroviral (ARV). Jurnal Penyakit Dalam Indonesia, 4(1), 2-4.

9. Kemenkes. (2013). Permenkes Rl: Pedoman Pecegahan HIV Ibu ke Anak. Jakarta: Kementrian Kesehatan Republik Indonesia.

10. Kemenkes. (2015). Pedoman Manajemen Program Pencegahan Penularan HIV dan Sifilis dari Ibu ke Anak. Jakarta: Kementrian Kesehatan Republik Indonesia.

11. Kemenkes. (2020). Pusdatin: HIVIAIDS. Jakarta: Kementrian Kesehatan Republik Indonesia.

12. Liansyah, T. M. (2018). Aspek Klinis dan Tatalaksana Bayi dengan Ibu Penderita HIVI AIDS. Jurnal Kedokteran Nanggroe Medika, 1(4), 32-38.

13. Maulida, F., \& Ghazali, P. L. (2019). Perilaku Menyusui pada Ibu dengan HIV-AIDS di Kota Yogyakarta. Jurnal MKMI, 15(4), 376-383.
14. Moseholm, E., \& Weis, N. (2020). Women living with HIV in high-income settings and breastfeeding. Journal International Mediicine, 287(1), 19-31.

15. Nurtikasari, A., \& Soraya, R. (2017). Perbedaan Pengetahuan Ibu Hamil Tentang Pencegahan Penularan Human Immunodeficiency Virus (HIV) dari Ibu ke Anak (PPIA) Sebelum dan Sesudah Diberi Penyuluhan (Desa Gampeng Kecamatan Gampengrejo Kabupaten Kediri). Jurnal Kebidanan, 6(2), 94-99.

16. Purwaningsih, N. A., Shodikin, M. A., \& Abrori, C. (2018). The Correlation between HIV / AIDS Positive Pregnant Mother with Infant APGAR Score in RSD dr.Soebandi Jember. Journal of Agromedicine and Medical Sciences, 4(3), 178-183.

17. Rabrageri, A. K. S., Siswosudarmo, R., \& Soetrisno. (2017). Faktor risiko transmisi virus HIV pada ibu hamil di papua. Jurnal Kesehatan Reproduksi, 4(1), 23-32.

18. Ramdhanie, G. G., Kep, M., Sp, N., An, K., Rukmasari, E. A., Kep, S., \& Kes, M. (2019). Perawatan Paliatif Pada Anak dengan HIV I AIDS Sebagai Korban Transmisi Infeksi Vertikal. Jurnal Kesehatan Bakti Tunas Husada, 19(2), 285-292.

19. Saroyo, Y. B. (2019). Penularan HIV Pada Bayi. Jakarta: Perkumpulan Obstetri dan Ginekologi Indonesia (POGI).

20. Schnack, A., Rempis, E., Decker, S., Braun, V., Rubaihayo, J., Busingye, P., ... Theuring, S. (2016). Prevention of Mother-to-Child Transmission of HIV in Option B+ Era: Uptake and Adherence During Pregnancy in Western Uganda. Clinical and Epidemiologic Research, 30(3).

21. Setiawan, N. A. P. H., \& Adi, M. S. (2020). Faktor Penghambat dalam Pelaksanaan Program VCT. Jurnal Penelitian Kesehatan Suara Forikes, 11(5), 346-350.

22. Solikhah, K., \& Hadjam, N. R. (2018). Validasi Modul : Terapi Kelompok Suportif Ekspresif 
untuk Menurunkan Depresi pada Wanita yang Mengalami Infertilitas Primer. Gadjah Mada Journal of Professional Psychology, 4(2), 102-115.

23. Tumangke, H., Tappy, M., \& Kendek, R. (2017). faktor-Faktor yang Mempengaruhi Efektivitas Pencegahan Penularan HIV dari Ibu ke Anak (PPIA) Di Kota Jayapura. Unnes Journal of Public Health, 6(4).

24. UNICEF Indonesia. (2018). Pencegahan Penularan HIV dari Ibu ke Anak. Jakarta: UNICEF Indonesia.
25. Wahyuni, S. (2016). Kepatuhan ibu pada masa kehamilan, persalinan, dan nifas dalam pelaksanaan program pencegahan penularan HIV. Jurnal Kebidanan Dan Keperawatan Aisyiyah, 12(1), 1-8.

26. Wudineh, F., \& Damtew, B. (2016). Motherto-Child Transmission of HIV Infection and Its Determinants among Exposed Infants on Care and Follow-Up in Dire Dawa City, Eastern Ethiopia. AIDS Research and Treatment, 2016. 